\begin{tabular}{|c|c|c|c|c|}
\hline Submission & Review Process & Revised & Accepted & Published \\
\hline $05-03-2020$ & $15-03 \mathrm{~s} / \mathrm{d} 25-04-2020$ & $29-05-2020$ & $30-06-2020$ & $30-06-2020$ \\
\hline
\end{tabular}

Jurnal Studi Sosial dan Politik, Vol. 4, No. 1, June 2020 (18-31)

ISSN 25978756

e ISSN 25978764

Jurnal Studi Sosial dan Politik Published by: FISIP Universitas Islam Negeri Raden Fatah Palembang

\title{
Transformation of Radicalism Discourse into Extremist Violence (Analysis of News on the Handling of Radical Movements in Indonesia)
}

\author{
Sunardi Panjaitan \\ Paramadina University \\ Email: panjaitansunardi@gmail.com
}

\begin{abstract}
This article explains how the transformation of the discourse of radicalism into extremist violence in media coverage. Radical movements tend to be interpreted as acts of violence. Not only terrorism but also discourse about the idea of building the Islamic state including the action and the radical movement. Therefore the state has to destroy radical movements or radicalism understandings. Especially the media coverage is important. But in the media coverage, the state labeled Islamic groups as radical groups. The labeling is caused by the government not having an overall idea or concept towards acts of terrorism or radical movements itself. That proof of radical movement in Indonesia always moves between two pendulums, after-action would be produced new regulation. When terror and violence occur, the government responds to these events by issuing a number of regulations and discourse several policies in the media. As a result, acts of terror tend to recur, and injustice and discrimination tend to be addressed to certain groups. Therefore, the transformation of radicalism into extremist violence as a response to the discourse on the handling of terrorism in Indonesia having an overall idea or concept.
\end{abstract}

Keyword: Radical Movement, Terrorism, media coverage, Extremist Violence

\begin{abstract}
Abstrak
Artikel ini menjelaskan bagaimana transformasi wacana radikalisme ke kekerasan ekstrimis dalam pemberitaan media. Gerakan radikal cenderung diartikan sebagai tindakan kekerasan. Tidak hanya itu, akar dari terorisme disebabkan oleh paham radikal (radikalisme). Namun wacana tentang radikalisme pun terus berkembang, bentuk dari tindakan atau aksi radikal juga yaitu gagasan membangun negara Islam. Oleh sebab itu negara penting untuk menangani gerakan radikal atau
\end{abstract}


paham radikalisme, terutama melalui pemberitaan media. Namun dalam pemberitaan media, negara melakukan labelisasi terhadap kelompok Islam. Labelisasi tersebut diakibatkan pemerintah tidak memiliki gagasan atau konsep yang menyeluruh terhadap tindakan terorisme atau gerakan radikal. Penangangan paham radikalisme di Indonesia selalu bergerak diantara dua bantul. Aksi dan regulasi. Ketika terjadi peristiwa teror dan kekerasan, pemerintah merespon peristiwa tersebut dengan menerbitkan sejumlah regulasi dan mewacanakan beberapa kebijakan di media. Akibatnya aksi-aksi teror cenderung berulang, dan ketidakadilan dan diskriminasi cenderung dialamatkan terhadap kelompok tertentu. Oleh sebanya transformasi radikalisme ke kekerasan ekstrimis sebagai respon terhadap wacana penanganan akasi teror di Indonesia dengan konsep dan gagasan secara menyeluruh.

Keyword : Gerakan Radikal, Terorisme, Pemberitaan, Kekerasan Ektrimis

\section{INTRODUCTION}

The explosion of the World Trade Center (WTC) building on September 11, 2001, in America was a place a starting point for the discourse of Islam and terrorism globally. Including Islam is labeled as a religion that has been a mastermind action of terrorism. Although the American Intelligence Center (CIA) had apologized for mistaking and justifying Islam (Osman Bin Laden) became the mastermind behind the explosion of WTC in 2019. It did not revoke the discourse which had taken root in terrorism. And in Indonesia itself has become public discourse. Especially after the event, the Bali Bomb was dated October 22, 2002.

The issue of terrorism has also arisen and is always associated with radical movements and/or radicalism. Terrorist acts that continue to repeat and proliferate such as Mega Kuningan Bombing (2009), Solo Bombing (2011), Book Bomb, and Bomb Thamrin (2016), and others increasingly strengthen terrorist acts related to radical movements or radicalism. Umar (2010) termed these various acts of terrorism as a radical Islamic movement. Radicalism was understood something against the state, using Islamism as an ideological foothold. And the radical Islamic groups in Indonesia are of serious concern. Because the eradication of terrorism must be integrated with destroying radical understanding and movement.

But the discourse of radicalism or radical movements continues to be debated. In addition to radicalism as the root of terrorism, the discourse about radicalism also develops in the idea to build the Islamic state (Daulah Islamiyah / Khilafah Islam). It has a long history in Indonesia. But Hadiz (2018) said that the idea to build the Islamic State was an Islamic political populism movement. The emergence of this Islamic movement as a political force in Indonesia for the freedom of the people (Islamic society) from oppression and exploitation.

So the discourse of radicalism widespread that is no longer focused on acts of terror. Entering also in the problems of political and economic systems such as democracy, capitalism, and imperialism that triggered a radical movement. This means of the radical Islamic movement is caused by poverty, oppression, and injustice that befell the people. So there arose a radical movement to fight the system that shackles it. From the growing discourse, labeling for radical groups is also widely 
carried out by the state/government. Various government discourses continue to be developed and campaigned. Especially relations and networks have been built by radical groups in Indonesia. The terrorist acts with the bombing that occurred have something to do with the Al Qaeda network, Jemaah Islamiyah (JI), ISIS, and others.

While radical group actions aimed at building Islamic systems and states are always linked to the Ihwanul Muslimin network, Hizbut-Tahrir, and also ISIS. Handling this radical movement, the government has taken some political policies. Among them are dismissing and or revoking permits of the Indonesian Hizb ut-Tahrir (HTI) organization. The government believes that radical ideas are built and developed in mosques, universities, and various other media and facilities.

This paper wants to focus on aspects of how discourse about radicalism in the media in the past year (2019). This discourse is interesting to study considering, in its development, that the campaign to deal with the radicalism movement in Indonesia is actually considered to target Islamic groups and organizations. Moreover, the National Counterterrorism Agency (2016) defines radicalism as an attitude that craves total and revolutionary change by overturning values that are drastically through violence (violence) and extreme actions. And the handling of radical movements in Indonesia is still considered selective logging, and the government is considered islamophobia.

Because of the handling of the radicalism movement in Indonesia is considered to only target Islamic groups and organizations, that some pressure groups have begun to voice the term radicalism to be changed into violent extremism. The extremism movement discourse developed over the reflection on the labeling of certain groups and religions that carry out acts of terror. In addition, the discourse was born from criticism of the handling of existing terrorist acts, which were considered ineffective, discriminatory, and unfair. Shifting of the discourse currently fills the scholar table and the various media today. And the media has become campaign tools to deal with terrorist movements and or radical Indonesian movements. Because the media provides total support for combating terrorist acts in Indonesia. Although acts of terror tend to continue to occur repeatedly in Indonesia. So in this article, will answer the research question, how is the handling of radical movements by the government so that gave birth to a shift in the discourse about radicalism to extremist violence in the media?

\section{Theory of Discourse on Preaching Terrorism and Radical Movements}

Using discourse theory, this article will show how the shift of discourse about the movement of radicalism to extremist violence in the media. Discourse analysis is an analysis used to see the use of language, both in writing, speech, myth, or other symbols as social practices (Eriyanto, 2008 and Williams, 2003).

The government divides the two groups that carry out radical movements in the release to the media. First, the groups terrorize with the bombs that termed terrorism. Second, groups that want to change the state system or want to establish an Islamic state (Daulah Islamiyah / Khilafah Islamiyah). That grouping had made by the government raised the pros and cons of the community. So that way the theory of discourse is operationalized by tracking the storylines used in the two pro and anti-discourse groups against the handling of radical movements/acts of terrorism in media 
reporting by the government. The tracking of discourse and storylines is limited to the data of the past one year period when the discourse of radicalism is transformed into extremist violent movements.

This article using the data is media clippings, infographics scattered in mainstream media that related to the radicalism news, expert scientific presentation documents, official documents that had issued by donor agencies such as the World Bank, and official pages of the parties involved in forming the discourse. It all will lead to debates about how the shifting of discourse about radicalism to extremist violence in the media and its handling by the government. And according to Ernesto Laclau and Chantal Moffee (1985), discourse theory presupposes that the socio-political process is the practice of discourse.

Savirani (2017) says the intended discourse is "articulation" or argumentation. "Articulation" is understood as "any activity/practice that builds relations between elements, including identity, which is the result of modification of discourse/articulation activities" (any practices establishing relations between elements such as identity, which is modified as a result of the articulatory practices). In line with that, by sharpening in several elements, Marteen Hajer (1995) understands discourse as "an assemblage of ideas, concepts, and categories that are produced, reproduced, and transformed, in specific practices and through these practices the meaning of social reality and physical reality are constructed". And in media coverage, discourse is built on the content (content) of media coverage. There is a relationship between content that is built with the social conditions of the audience or society and political dynamics in the country. According to Morely in Rachma Ida (2014) is that there is a complete discourse (thick understanding) between the news content (media) with the audience. This is famous for the Cultural Studies research which became a starting point in observing the media.

The discourse of radicalism and terrorism in media reporting is inseparable from this relation. The state, in this case, that is the government is building discourse in the media to deal with radical movements and or terrorism. And the response of the people is different, and then a new discourse emerges with the term extremist violence as an alternative in countering radical movements or acts of terrorism that tend to recur. To understand the transformation of the discourse is to look at and tracking storylines, namely "a kind of narrative used by the state through its instruments namely the Police and BNPT or the Ministry of Religion with the groups involved and considered exposed to radical movements to see the social phenomenon." And according to Marteen Hajer (1995) Storylines represent a social reality that is done by combining various domain arguments. Storylines also provide a symbolic reference tool for actors to create a common understanding. In other words, storylines are not just language with the content of certain arguments in them, but political tools used to build and overcome various variations of discourse.

\section{RESEARCH METHOD}

This article explains how the shift of discourse about radicalism to extremist violence in the media and its handling by the government. The focus of his writings is on media coverage in handling radical movements in Indonesia. Therefore, in this article, we dig deep information from the media 
in handling terrorist acts or radical movements by the state or government. The article uses a media monitoring research approach to analyze problems holistically, this article focuses on the issue of shifting discourse about the movement of radicalism to extremist violence in media reporting and its handling by the government.

The data collected by the author in this paper used purposive sampling to analyze all news related to the research theme. According to Sugiyono (2017), purposive sampling is a data source sampling technique with certain considerations. The reason for using a purposive sampling technique is because not all samples have criteria that fit the phenomenon under study. Therefore, the authors chose a purposive sampling technique that sets out certain considerations or criteria that must be met by the samples used in this study.

The object of this research is the reporting of radicalism news in 11 national online media in a span of one year (January-December 2019). The eleven online media are Tempo.co, Detik.com, Republika.co.id, Kompas.com, Cnnindonesia.com, Jpnn.com, Liputan6.com, Medcom.com, Sindonews.com, Viva.co.id, and Akurat.co. These media were chosen with various considerations ranging from the distribution of media, media segments, ratings, and media ownership.

\section{RESULTS AND DISCUSSIONS}

\section{Radical Movement and Media Coverage in Indonesia}

Radical movements are associated with acts of violence. The public meaning of radical movements as acts of violence has become a culture. Moreover, scholars, almost all agree on the roots of acts of terrorism because of radicalism/radicalism. Nafi Muthohirin (2015), Hamid Nur (2016), Harun Rosyid (2018), Moch. Kholid Afandi (2019) said that radicalism is an idea or notion of change by means of violence. This means that the meaning of radicalism has been hegemonic as an act of violence.

The history of the radical movement was carried out by a group called radical Islamic groups. Hamid Nur (2016) said that the group referred all of its actions to a very basic religious doctrine or very high religious fanaticism and then it is not uncommon for adherents of these radical understandings to use violence to people that different understandings/sects to accept the religious thinking they are. And Mark Juergensmeyer said that the group used old-fashioned views and often used violence to teach their beliefs. They like to carry out acts of terror, which means to frighten or cause fear.

Leni Winarni (2014) has tried to understand the views of radicalism in Indonesia differently. Radicalism, according to her, is not only associated with acts of violence but also can be interpreted as a total purification of Islamic teachings (purification). Because of the meaning of radicalism that had been hegemony earlier, it tends to attach radicalism with violence. So the thought of radicalism is manifested in violence. So labeling the radical movements was terrorists (acts of violence). And acts of terrorism tend to be associated with Islam or Islamic symbols and attributes. Another term is labeling Islam.

The long history of the meanings and terms of the radical movement cannot be separated from the discourse that has been built by the state through its instruments (the National Police, the Ministry 
of Religion, BNPT, etc.). Radicalism itself is a threat to the Republic of Indonesia (NKRI), which is a threat to the Pancasila ideology. Because of radicalism as understanding aims to change the basis of the state or Pancasila. Therefore radicalism itself is considered the extreme of the right group. And the doctrines of radicalism most often are suicide bombings, jihad, and intolerance. And the cause is in thought and politics. The discourse developed by the state is articulated through media coverage. And until now it is still very massive being repeated by the state.

So far, the news about eradicating acts of terrorism aims to counter radicalism. Gun Gun Heryanto (2017) termed as media literacy. Media literacy aims to counter radicalism in away. First, is the knowledge of accessing news or information in the media. Through this knowledge, it will help the user to minimize distorted information. Second, is skill or ability. This is related to the purpose of someone accessing news. With this, the user will understand the source that is read when accessing news through internet media. Third, is attitude. This is related to the attitude and response have taken by the public after receiving the news. Is the news something that is true and acceptable or just the opposite. Therefore the government is very interested in reporting the danger of radicalism in media reporting with the aim of preventing acts of terrorism.

\section{Media News Content}

Reports on the issue of radicalism throughout 2019 are always moving that between the two pendulums are action and regulation. The "action" pendulum is related to violent incidents that be handled by security forces in the field. For example, the stabbing act the Coordinating Minister for Political Law and Security Wiranto in Pandeglang Banten, and the bomb terror that occurred at Medan Police. This incident was followed by a series of arrests of stabbing perpetrators and the network behind them by the police. Discourse about radicalism in the media has strengthened again after the stabbing incident. In fact, if pulled back, the coverage of radicalism has decreased quite dramatically after the 2019 elections.

\begin{tabular}{|c|c|}
\hline Month & Number of News \\
\hline January & 84 \\
\hline February & 51 \\
\hline March & 85 \\
\hline April & 40 \\
\hline May & 104 \\
\hline June & 118 \\
\hline July & 188 \\
\hline August & 256 \\
\hline September & 86 \\
\hline October & 625 \\
\hline
\end{tabular}




\begin{tabular}{|c|c|}
\hline November & 788 \\
\hline December & 68 \\
\hline
\end{tabular}

\section{Table 1}

\section{The Trends of Radicalism News in 2019}

While the pendulum "regulation" associated with policies and regulations initiated by the government to overcome the understanding of radicalism. A number of policies that were planned by the government after Wiranto's stabbing included the banning of trousers and veils in state institutions. Another policy that was discussed by the government was to monitor lecture materials in mosques made by the Vice President KH. Ma'ruf Amin. While related to regulations, the Government seems to have the momentum to accelerate the issuance of Government Regulation Number 77 of 2019 concerning the Prevention of Terrorism Crimes. Then, the issuance of the Joint Decree (SKB) is on Handling Radicalism among the State Civil Apparatus (ASN).

The incidents stabbing of Wiranto and bomb terror in Medan Police which ware followed by a series of policy discourse of the government made the escalation of the news about radicalism back strong. This shows that the phenomenon of radicalism was not entirely dependent and determined by the phenomenon of electoral politics. This means that radicalism as a phenomenon or problem has deeper roots so that it has timeless power.

The reporting of radicalism is also dominated by discourse battles both by the government and nongovernment groups. These discourse battles are illustrated by the narratives delivered by the government about the actions of radicalism, the space for spreading radical ideas, groups associated as radical groups, and efforts to tackle radicalism by the government. These narratives later received a rejection from various parties outside the government.

The government seems to be trying to construct an understanding of radicalism closely that related to certain groups. This can be seen from a series of policies undertaken to combat the spread of radicalism. Prohibition of veils and Cingkrang pants is the government's attempt to associate radical ideas related to groups that use veils and Cingkrang pants. 


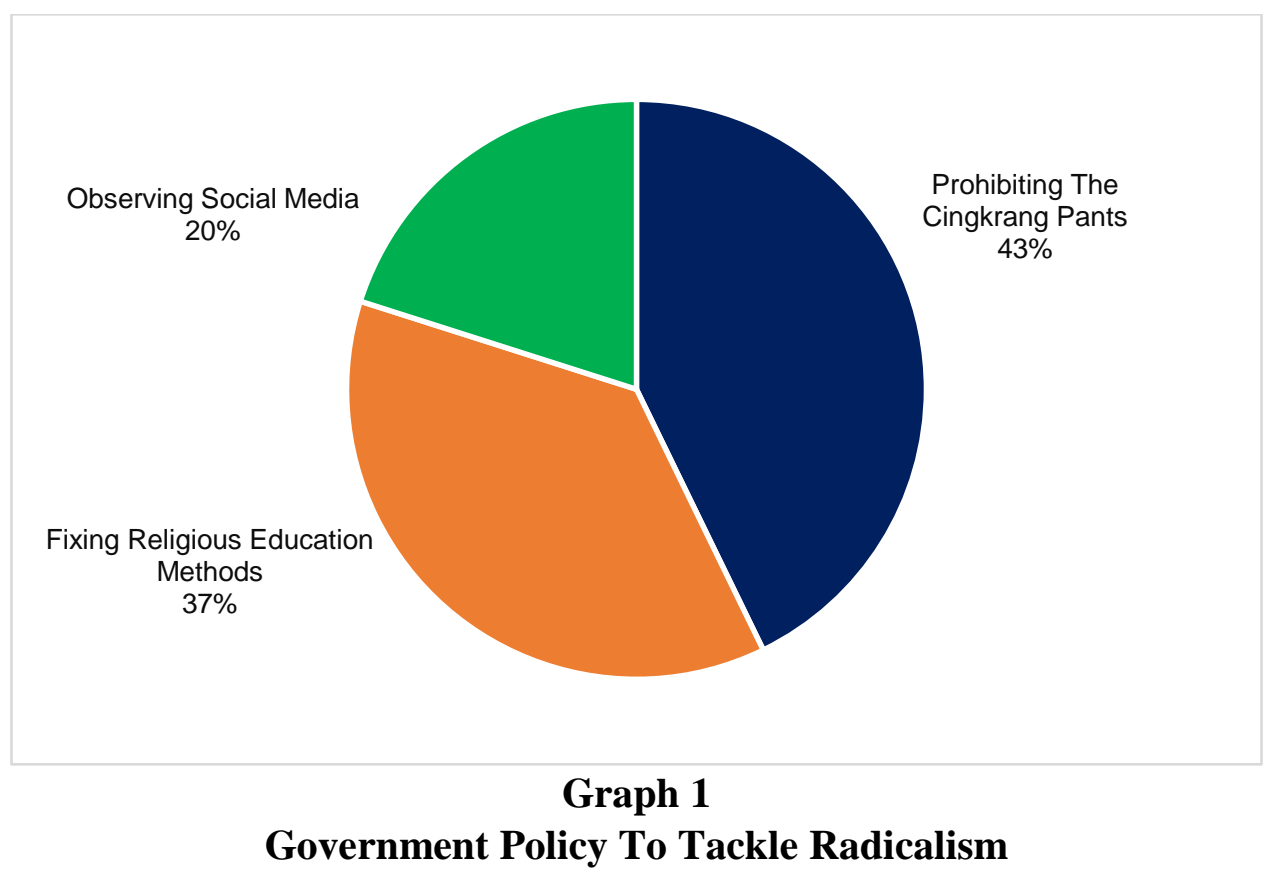

Other prevention efforts by the government are also always associated with certain groups and religions. Such as to fix religious education methods tend to target religious education methods in Islamic schools both boarding schools and other Islamic educational institutions. In this context, the government wants to change the lessons of Islamic history by eliminating content containing caliphate and war which is considered to have contributed to the spread of radical ideas in Indonesia. Likewise with the policy to observe social media. Where the government always links the accounts associated with certain groups to be monitored specifically in order to prevent the spread of content that smells of radicalism on social media.

A number of these preventive measures were taken because the government stated that the spread of radical understanding was carried out by certain groups through various media channels. Based on monitoring the coverage of radicalism in 2019, the media to spread radicalism is carried out through several channels. The biggest is through social media and websites. Furthermore, through study groups and through campus organizations. 


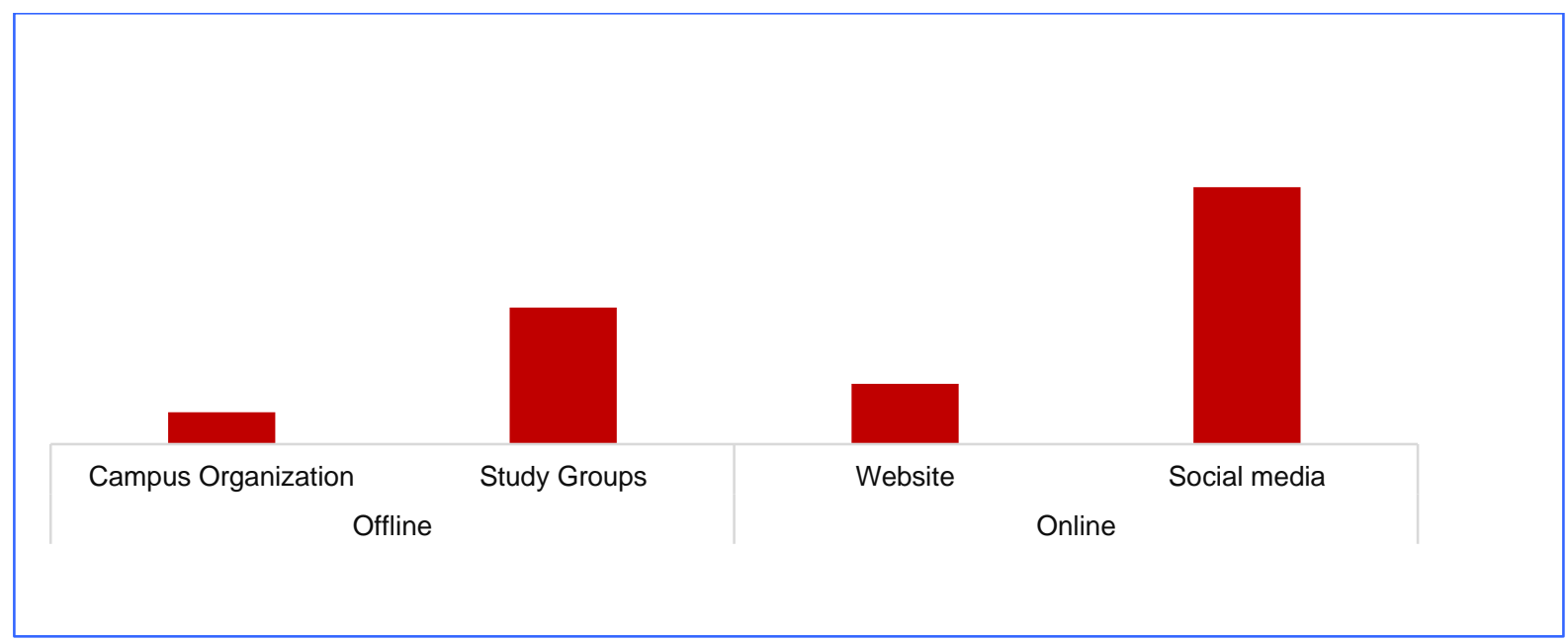

Graph 2

Media Spread Radicalism Based on Media Coverage Throughout 2019

In the context of news sources, government agencies are the main sources of media coverage in relation to radicalism. The National Police is the institution with the largest source of news because of handling taken by the National Police against acts of terrorism both that occurred in the Wiranto stabbing incident and the bomb terrorist acts in Medan Police. While the Ministry of Religion became another government institution which is quite a lot of sources of news along with various discourses and policies to counter radicalism. Conversely, those who are counter to the government do not get much news coverage.

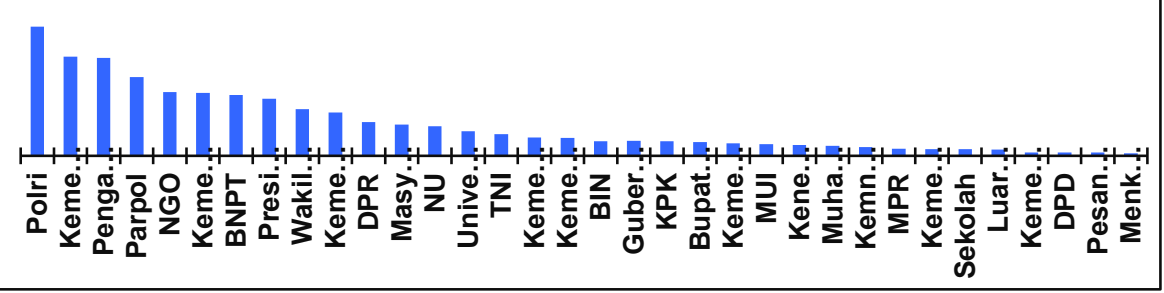

Graph 3

Sources of Media Coverage Related to Radicalism

From research on media coverage of radicalism throughout 2019, there are a number of discourses to replace the term radicalism with other terms such as violent extremism and religious manipulators. The transformation of radicalism into extremist violence arose during the Commission III DPR RI Meeting with the National Counterterrorism Agency. While the term religious manipulator emerged from President Joko Widodo when was opening a limited meeting on the topic of Submission of Programs and Activities in the Field of Politics, Law, and Security in the Office of the President, Thursday, 31 October 2019.

The emergence of the discourse of the change of the term radicalism into extremist violence or religious manipulators is based on the argument that radicalism is considered likely to target certain 
groups in Indonesia. The term radicalism is considered only to label the right group or religious group in this context is the religion of Islam.

\section{State Discourse and Powerlessness in Handling Radical Movements}

Efforts to deal with radical movements in Indonesia by the government from the beginning did not seem to have a clear and measurable concept. Based on data from media coverage during 2019 on radicalism, the handling of radical movements in Indonesia is always reactive. Always moving between two pendulums. Action and regulation.

\begin{tabular}{|c|c|c|}
\hline No & Action & Regulation/Policy \\
\hline 1 & $\begin{array}{l}\text { Stabbing Coordinating Minister for } \\
\text { Politics, Law and Security Wiranto }\end{array}$ & $\begin{array}{l}\text { 1. The arrest of parties related to the } \\
\text { perpetrator's network. } \\
\text { 2. Discourse on the prohibition of veils and } \\
\text { pants in the environment of state } \\
\text { institutions }\end{array}$ \\
\hline 2 & Terror of Bom in Polresta Medan & $\begin{array}{l}\text { 1. The arrest of parties related to the } \\
\text { perpetrators' screams. } \\
\text { 2. The issuance of Government Regulation } \\
\text { Number } 77 \text { the Year } 2019 \text { concerning } \\
\text { Prevention of Terrorism Criminal Acts. } \\
\text { 3. The discourse of monitoring on the } \\
\text { content of lectures in the mosque and } \\
\text { Majelis Taklim. } \\
\text { 4. Joint Decree (SKB) of Three Ministers of } \\
\text { Handling Radicalism among the State } \\
\text { Civil Apparatus (ASN). } \\
\text { 5. Monitoring social media related to } \\
\text { radicalism content. } \\
\text { 6. Launch of the ASN Complaints } \\
\text { Application. }\end{array}$ \\
\hline
\end{tabular}




\begin{tabular}{|l|l|l|}
\hline | & $\begin{array}{r}\text { 7. Review the religious education } \\
\text { curriculum by removing material about } \\
\text { the Khilafah and the history of warfare. }\end{array}$ \\
\hline
\end{tabular}

Table 2

\section{Government Action and Regulation in Dealing with Radical Movements in Indonesia}

This data also confirms the government's policy during handling terrorist movements and radical understanding in Indonesia. If drawn far back, after the Bali Bombings I and II, the Government had responded to the incident by giving birth to Law Number 1 of 2002 concerning the Eradication of the Criminal Acts of Terrorism. The birth of Law No. 1 of 2002 was followed by the Establishment of the Special Anti-Terrorism Detachment 88 by the Indonesian National Police in 2004.

Although the legal instruments had been prepared, as well as special teams that work against terrorism, in its development, the acts of terror in Indonesia have not decreased. Conversely, terrorists are able to transform and develop networks. A number of bomb terrorism occurred again, for example, bomb terror in JW Marriott and Ritz Carlton Hotel, Jakarta in 2009, bomb terror in Sarinah Plaza in 2016, and bomb terror in Kampung Melayu, Jakarta. The government calls Law Number 1 the Year 2002, considered to be no longer sufficient as a legal umbrella to eradicate terrorism because security forces are deemed not to have the authority to take action without any terrorist events. The government then planned to revise Law Number 1 of 2002 with a number of additional articles, including strengthening the authority of the National Intelligence Agency (BIN).

The climax of the debate about the revision of the law in 2018. A number of acts of terror occurred again in 2018, that started with the bomb terror in Mako Brimob, Depok, then followed by a series of bomb terror in three churches in Surabaya and Surabaya Police. Next was the bombing in Riau Police and a suicide bombing in Sibolga, North Sumatra. The series of acts of terror became the legitimacy for the government to revise Law Number 1 of 2002. Then published Law Number 5 of 2018 which was a revision of Law Number 1 of 2002.

Along with the many acts of terrorism that occurred, the discourse on the understanding of radicalism also experienced strengthening. Acts of terrorism are considered as part of the implementation of radical ideology. The phenomenon of radicalism and terrorism has endangered the existence of the state especially and a sense of security in society. Therefore this movement has to be watched out by the state. Mas'ud (2014) suggests three reasons why radical movements have to be watched out by the state. First, the radical movement aims to replace the established state ideology with the ideology of the group concerned without considering the interests of other groups' ideologies. Second, the presence of radicalism raises social instability and greed because it is militant, violent, tends to be anarchic, unwilling to compromise, and third, the impact of radicalism can threaten the existence of the authorities. 
These three reasons also seem to be the basis for the government and pro-government groups to label groups that are considered radical and want to replace the state ideology. As a result, the government took steps to dissolve the Indonesian Hizb ut-Tahrir (HTI) in 2017 because the activities carried out by HTI were considered to have caused conflicts in the community that could threaten the security and public order, as well as endangers the integrity of the Unitary State of the Republic of Indonesia.

Although the government has never specifically linked Islamic groups with radical movements, the news coverage shows that there is an effort to herd an opinion that certain Islamic groups and organizations are linked to radical groups. This can be seen from a number of prevention efforts undertaken by the government which tends to target groups and Islamic culture. Such as the prohibition of veils and trousers that are identical with the Salafi movement and improvement of religious education in Islamic educational institutions or monitoring efforts of taklim assemblies which are also associated with Islam.

This labeling certainly causes injustice and discrimination for Islamic groups. In addition, this labeling also has the potential to trigger conflicts between groups. And this indication is very visible in the past year, where friction between groups often occur. Stigmatization of veiled people and wearing conical pants as a fundamentalist and radical group has made people suspicious of each other. In fact, it could be that the use of veils and trousers is part of a fashion trend or an indication of strengthening one's religious understanding which believes that wearing a veil is part of the implementation of religious teachings that it adopts.

The handling of radical understanding carried out by the government by labeling Islamic groups as radical groups are what has been rejected by various parties. The meaning of government radicalism is considered to discredit religious practices. The government is considered to simplify the problem of radicalism only as much as a veil and trousers. In fact, the perpetrators of terror and violence are not only carried out by groups with a veil and cingkrang fashion style but also acts of terror that occurred in New Zealand, for example, carried out by groups that actually do not like Islamic groups. Likewise, the action that occurred in Europe and America targeted terrorist groups. The powerlessness of the government in handling with radicalism is what gave birth to the discourse to replace the term radicalism with extremist violence. This change in the term is expected to enable the government to develop a comprehensive and comprehensive agenda for handling acts of terror and violence. Not partial and reactive. And do not target certain groups, especially Islamic groups. Errors in understanding radical understanding and attempts to label radical movements with certain groups are considered to be the cause of the failure of handling violence in the name of religion in Indonesia. Because when the government labels certain groups as radical groups, there will be resistance. So that government efforts to involve all groups in tackling and overcoming radicalism are always deadlocked.

\section{CONCLUSION}

Efforts to deal with radical movements carried out by the government so far have no clear and measurable conceptions. Everything is done with partial and reactive. News about radicalism in the media throughout 2019 shows that the handling of radicalism in Indonesia always moves 
between two Bantul. Action and regulation. When terror and violence occur, the government responds to these events by issuing a number of regulations and discussing several policies.

Unfortunately, the policies taken had targeted certain groups, in this context the Islamic group. This policy was born from the imposition of radicalism which was considered wrong from the beginning. The government was actually considered to corner religious practices in interpreting radicalism. In order to be more comprehensive in handling this radical movement, a discourse emerged to change the term radicalism to extremist violence. With this change, it is hoped that the government will no longer target certain groups in the fight against radicalism. This term change is also expected by the government to be able to develop an agenda for tackling radicalism in a more comprehensive and measurable way. 


\section{REFERENCES}

BNPT (2016). Strategi Menghadapi Radikalisme, Terorisme-ISIS https://belmawa.ristekdikti.go.id/wp-content/uploads/2016/12/Strategi-MenghadapiPaham-Radikalisme-Terorisme.pdf

Eriyanto (2008). Analisis Wacana: Pengantar Analisis Teks Media. LKiS: Yogyakarta.

Fatimah, S., \& Syukur, Y. (2019). Al-Qaeda's New Orientation After the Death of Osama bin Laden. Jurnal Studi Sosial Dan Politik, 3(2), 130-145. https://doi.org/https://doi.org/10.19109/jssp.v3i2.4390

Hadiz, Vedi R. (2018). Imagine All the People? Mobilising Islamic Populism for Right-Wing Politics in Indonesia. Journal of Contemporary Asia, Vol. 48, No. 4, 1-18.

Hajer, Marteen (1995). The Politics of Environmental Discourse. Oxford: Oxford University Press Ida, Rachma (2014).Metode Penelitian: Studi Media dan Kajian Budaya. Jakarta: Prenadamedia Khamid, Nur. Bahaya Radikalimse terhadap Negara Kesatuan Republik Indonesia. Jurnal of Islamic Studies and Humanities, Vol. 1, No. 1.

Moffee, Chantal \& Laclau, Ernesto (1985). Hegemony and Socialist Strategy. London: Verso.

Muthohiri, Nafi (2015). Radikalisme Islam dan Pergerakannya di Media Sosial. Jurnal Afkaruna Vol. 11, No. 2, 240-259.

Sari, D.A.C Benedicta. Media Literasi dalam Kontra Propaganda Radikalisme dan Terorisme Melalui Media Internet. Jurnal, Benediktadian@gmail.com.

Savirani, Amalinda (2017).Pertempuran Makna Publik dalam Wacana Pembangunan Reklamasi Teluk Jakarta. Jurnal Prisma Vol. 36 No. 1, 112-126.

Sugiyono (2017).Metode Penelitian Kuantitatif, Kualitatif, dan R\&D. Bandung: Alfabeta

Umar, Ahmad Rizky M (2010). Melacak Akar Radikalisme Islam di Indonesia.Jurnal Ilmu Sosial dan Ilmu Politik, Vol. 14, No.2, 169-186.

Williams, Kevin (2003). Understanding Media Theory. New York: Oxford University Press.

Winarni, Leni (2014).Media Massa dan Isu Radikalisme Islam. Jurnal Komunikasi Massa Vol. 7 No. 2, 159-165 